\title{
Pathological aspects of breast cancer in Indonesian females, applying a modified WHO classification. A joint study between Indonesia and Japan
}

\author{
Gunawan Tjahjadi*, Goi Sakamoto ${ }^{\dagger}$, Didid Tjindarbumi”, Susumu Watanabe ${ }^{\S}$, Joedo Prihartono \\ Yoshiyuki Ohno"ll, Santoso Cornain*, Esti Soetrisno*, Endang Sri Roostini*, Muchlis Ramli, Idral Darwis", \\ Setyawati Budiningsih , Sadao Suzuki ${ }^{\natural l}$, Kenji Wakai ${ }^{\dagger}$, Drupadi S Dillon^, Susilowati Herman^.
}

\begin{abstract}
Abstrak
Dari aspek patologi diteliti kembali varian histologik karsinoma payudara dan dibandingkan dengan kasus-kasus dari Jepang. Dipakai klasifikasi yang dianjurkan oleh Japanese Breast Cancer Society, yang membagi lagi karsinoma mammae duktal invasif menjadi 3 subtipe, yaitu: tipe papilotubuler, solid-tubuler dan skirus. Dari Indonesia ada 515 kasus yang ditangani oleh Rumah Sakit Umum Pusat Nasional Dr. Cipto Mangunkusumo (RSCM), berasal dari penelitian ke-1 dan ke-2, sedangkan dari Jepang ada 445 kasus yang ditangani oleh Cancer Institute Hospital (CIH). Di RSCM ditemukan sebanyak 0.97\% karsinoma noninvasif, 89.14\% karsinoma duktal invasif dan $9.50 \%$ tipe khusus. Di CIH ditemukan sebanyak $7.4 \%$ karsinoma non-invasif, $80.4 \%$ karsinoma duktal invasif dan $11.3 \%$ tipe khusus. Insiden karsinoma duktal noninvasif di RSCM lebih rendah daripada CIH dengan perbedaan 6.43\%. Di antara subtipe karsinoma duktal invasif, tipe skirus-lah yang paling banyak ditemukan pada kedua kelompok (RSCM dan CIH), dengan insiden 50.49\% (RSCM) dan $43.6 \%$ (CIH). Subtipe yang paling sedikit di RSCM ialah tipe papilotubuler, sedangkan di CIH ialah tipe solid-tubuler. Tipe khusus ditemukan sebanyak 5 varian di RSCM, sedangkan di CIH 7 varian. Insiden karsinoma musinosum dan karsinoma lobuler invasif di RSCM lebih rendah daripada di CIH, sedangkan karsinoma moduler lebih tinggi. Insiden penyakit Paget juga lebih rendah di RSCM.
\end{abstract}

\begin{abstract}
From the pathological aspect, we analyzed again the histological variants of breast cancer and compare them with cases from Japan. We used the classification recommended by the Japanese Breast Cancer Society, which divided the invasive ductal carcinoma of NOS (no otherwise specified) of the WHO classification into 3 subtypes, namely papillotubular, solid-tubular and scirrhous carcinoma. We had 515 cases from Indonesia (1 ${ }^{\text {st }}$ batch and $2^{\text {nd }}$ batch) treated at the Dr. Cipto Mangunkusumo National Central General Hospital (RSCM) and 445 cases from Japan, treated at the Cancer Institute Hospital (CIH). The RSCM cases had 0.97\% noninvasive carcinoma. $89.14 \%$ invasive ductal carcinoma and $9.50 \%$ of the specialtypes. The CIH cases had $7.4 \%$ noninvasive carcinoma, $80.4 \%$ invasive ductal carcinoma and $11.3 \%$ of the special types. The incidence of noninvasive ductal carcinoma was lower at RSCM, with a $6.43 \%$ difference. Among the subtypes of invasive ductal carcinoma, the scirhous carcinoma was the most common in both groups (RSCM and CIH), with an incidence of $50.49 \%$ (RSCM) and $43.6 \%(C I H)$. The least common at RSCM was the papillotubular type, while at the CIH it was the solid-tubular type. Among the special types, only 5 variants were encountered at RSCM and 7 at CIH. The incidences of mucinous carcinoma and invasive lobular carcinoma were lower at RSCM, while the medullary carcinoma was higher. The incidence of Paget's disease was also lower at RSCM.
\end{abstract}

Keywords: Pathological, breast cancer, WHO-classification, Japan-Indonesia study.

* Department of Pathology, Faculty of Medicine, University of Indonesia, Jakarta 10430, Indonesia

+ Department of Pathology, Cancer Institute Hospital, Tokyo I70, Japan

* Department of Surgery, Faculty of Medicine, University of Indonesia, Jakarta 10430, Indonesia

\$ Department of Surgery, Cancer Institute Hospital, Tokyo 170, Japan

- Department of Community Medicine, Faculty of Medicine, University of Indonesia, Jakarta 10320, Indonesia

"I Department of Preventive Medicine, School of Medicine, Nagoya University, Nagoya 466, Japan

^ Department of Nutrition, Faculty of Medicine, University of Indonesia, Jakarta 10430, Indonesia

\section{INTRODUCTION}

Breast cancer is a worldwide and serious disease, which create a major public health problem. There are geographic differences in their incidence rate, being higher in Northern America and Europe than in Asian countries and Japan. Its frequency is increasing during the last 15 years, especially among women with a high socioeconomic status, namely from 12.116.6 to 21 per 100,000 females in Japan and from 71.7 to 91 per 100,000 females in Northern America. In Singapore the incidence of all ethnic groups almost doubling over the last 20 years. In Indonesian, 
the data collected from 13 Pathology Laboratories spread throughout Indonesia, showed that breast cancer ranked the second among females, with $18.03 \%$ relative frequency (ASCAR = age standardized cancer ratio 17.84\%) in 1988 and $18.44 \%$ (ASCAR $17.46 \%)$ in 1989.

These differences have attracted investigators to look upon several aspects of breast cancer, including epidemiological, clinical, pathological, and nutritional aspects. A Joint Study on etiology and Clinicopathology of breast cancer has been conducted since 1988, between Indonesia and Japan.

In the first batch of a three years study we encountered dissimilar pathological finding. The Cipto Mangunkusumo National Central General Hospital (RSCM) cases had lower incidences of noninvasive ductal carcinoma, mucinous carcinoma and invasive lobular carcinoma than cases from CIH (Cancer Institute Hospital, Tokyo). Medullary carcinoma was more frequent at the RSCM. An extended study was done to include nutritional analysis. From the pathological aspects we analyzed again the histological variants of breast cancer and compare with the cases from Japan.

\section{MATERIALS AND METHODS}

Table 1. Histological classification of breast tumors (Japanese Breast Cancer Society, 1984)

Malignant (Carcinoma)

1. Noninvasive carcinoma

a. Noninvasive ductal carcinoma

b. Lobular carcinoma in situ

2. Invasive carcinoma

a. Invasive ductal carcinoma

al. Papillotubular carcinoma

a2. Solid-tubular carcinoma

a3. Scirrhous carcinoma

b. Special types

b1. Mucinous carcinoma

b2. Medullary carcinoma

b3. Invasive lobular carcinoma

b4. Adenoid cystic carcinoma

b5. Squamous cell carcinoma

b6. Spindel cell carcinoma

b7. Apocrine carcinoma

b8. Carcinoma with cartilaginous and or osseous metaplasia

b9. Tubular carcinoma

b10. Secretory carcinoma

b11. Others

3. Paget's disease

Note: See Appendix for the principles and details of the classification.
Two hundred and twenty six cases of breast cancer were available. Some of these cases the diagnosis of breast cancer were performed at another Hospital without mentioning the subtypes. This occurred in 11 cases, so for histopathological analysis we had 215 cases. The classification used that recommended by the Japanese Breast Cancer Society, which divided the invasive ductal carcinoma of N.O.S (no otherwise specified) of the WHO classification into subtypes, papillotubular, solid tubular and scirrhous carcinoma.

\section{RESULTS}

The case distribution by histological type is shown in Table 2 .

Table 2. Case distribution of histological types of breast cancer (1992-1995)

\begin{tabular}{lcc}
\hline Histological types & Number of cases & $\%$ \\
\hline $\begin{array}{l}\text { Noninvasive carcinoma } \\
\text { a. Noninvasive ductal carcinoma }\end{array}$ & 1 & 0.46 \\
b. Lobular carcinoma in situ & & \\
& & \\
Invasive carcinoma & & \\
a. Invasive ductal carcinoma & 15 & 6.98 \\
a1. Papillotubular & 66 & 30.70 \\
a2. Solid-tubular & 113 & 52.86 \\
a3. Scirrhous & & \\
b. Special types & 4 & 1.86 \\
b1. Mucinous carcinoma & 10 & 4.65 \\
b2. Medullary carcinoma & 5 & 2.33 \\
b3. Invasive lobular carcinoma & 1 & 0.46 \\
b4. Squamous cell carcinoma & 215 & 100.00 \\
\hline To t a l & & \\
\hline
\end{tabular}

The invasive ductal carcinoma accounted for $90.24 \%$ of the cases, followed by the special types with $9,3 \%$. Only 1 case of noninvasive ductal carcinoma was found $(0.46 \%)$. In one case of papillotubular carcinoma a coincidental finding with a lobular carcinoma in situ was seen. When we compiled the 1 st batch and the 2 nd batch of the study, the results is shown in Table 3 . 
Table 3. Histological types and case distribution of breast cancer of the whole study (1988-1995)

\begin{tabular}{lcc}
\hline \multicolumn{1}{c}{ Histological types } & Number of cases & $\%$ \\
\hline $\begin{array}{l}\text { Noninvasive carcinoma } \\
\text { a. Noninvasive ductal carcinoma }\end{array}$ & 5 & 0.97 \\
b. Lobular carcinoma in situ & & \\
& & \\
Invasive carcinoma & & \\
a. Invasive ductal carcinoma & 54 & 10.49 \\
al. Papillotubular & 145 & 28.6 \\
a2. Solid-tubular & 260 & 50.49 \\
a3. Scirrhous & & \\
b. Special types & 8 & 1.55 \\
b1. Mucinous carcinoma & 27 & 5.24 \\
b2. Medullary carcinoma & 12 & 2.33 \\
b3. Invasive lobular carcinoma & 1 & 0.19 \\
b4. Adenoid cystic carcinoma & 1 & 0.19 \\
b5. Squamous cell carcinoma & & \\
& 2 & 0.39 \\
\hline Paget's disease & 515 & 100.00 \\
\hline \multicolumn{2}{l}{ To t a 1 }
\end{tabular}

The most common was the invasive ductal carcinoma with $89.14 \%$. The special types with $9.50 \%$. Only 5 cases of noninvasive ductal carcinoma were found, comprised only $0.97 \%$. Among the special types, the medullary carcinoma was the most common, with $5.24 \%$ incidence rate. When we compare the whole cases with cases from Japan, the result is seen in Table 4 .

The RSCM cases had $0.97 \%$ noninvasive carcinoma, $89.14 \%$ invasive ductal carcinoma, and $9.50 \%$ of the special types. The $\mathrm{CIH}$ cases had $7.4 \%$ noninvasive carcinoma, $80.4 \%$ invasive ductal carcinoma, and $11.3 \%$ of the special types. The incidence of noninvasive ductal carcinoma is lower at the RSCM, with a $6.43 \%$ difference.

Among the special types at the RSCM only 5 variants were encountered, while at the $\mathrm{CIH}$, there were 7 variants. The incidences of mucinous carcinoma and invasive lobular carcinoma were lower at the RSCM, while the medullary carcinoma was higher. The incidence of Paget's disease was also lower at the RSCM. The age incidences of the 226 cases of the $2^{\text {nd }}$ batch of the study are presented in Table 5 .

Table 4. Calse distribution of histological types of breast cancer

\begin{tabular}{|c|c|c|c|c|}
\hline \multirow[t]{2}{*}{ Histological Types } & \multicolumn{2}{|c|}{ RSCM (1988-1995) } & \multicolumn{2}{|c|}{$\mathrm{CIH}(1989)$} \\
\hline & Number of cases & $\%$ & Number of cases & $\%$ \\
\hline \multicolumn{5}{|l|}{ Noninvasive carcinoma } \\
\hline a. Noninvasive duclal carcinoma & 5 & 0.97 & 33 & 7.4 \\
\hline \multicolumn{5}{|l|}{ b. Lobular carcinoma in situ } \\
\hline \multicolumn{5}{|l|}{ a. Invasive ductal carcinoma } \\
\hline a.1. Papilotubular & 54 & 10.49 & 86 & 19.3 \\
\hline a.2. Solid-tubular & 145 & 28.16 & 78 & 17.5 \\
\hline a.3. Scirthous & 260 & 50.49 & 194 & 43.6 \\
\hline \multicolumn{5}{|l|}{ b. Special types } \\
\hline bl. Mucinous carcinoma & 8 & 1.55 & 16 & 3.6 \\
\hline b2. Medullary carcinoma & 27 & 5.24 & 6 & 1.3 \\
\hline b3. Invasive lobular carcinoma & 12 & 2.33 & 20 & 4.5 \\
\hline b4. Adenoid cystic carcinoma & 1 & 0.19 & - & - \\
\hline b5. Squamous cell carcinoma & 1 & 0.19 & 1 & 0.2 \\
\hline b6. Spindle cell curcinoma & - & - & 1 & 0.2 \\
\hline b7. Apocrine carcinoma & - & - & 2 & 0.4 \\
\hline b8. Tubular carcinoma & & - & -5 & 1.1 \\
\hline Paget's disease & 2 & 0.39 & 3 & 0.7 \\
\hline Total & 515 & 100.00 & 445 & 100.00 \\
\hline
\end{tabular}


Table 5. Case distribution by age at operation/biopsy (RSCM, 1988-1995)

\begin{tabular}{ccc}
\hline Age & Number of Cases & $\%$ \\
\hline $20-$ & 3 & 1.33 \\
$30-$ & 63 & 27.87 \\
$40-$ & 68 & 30.09 \\
$50-$ & 66 & 29.20 \\
$60-$ & 23 & 10.18 \\
$70-$ & 3 & 1.33 \\
\hline Total & 226 & 100.00 \\
\hline
\end{tabular}

In Table 6 is shown the case distribution of the whole cases by age.

Table 6. Case distribution by age of the whole cases (RSCM, 1988-1995)

\begin{tabular}{ccc}
\hline Age & Number of cases & $\%$ \\
\hline $20-$ & 16 & 3.04 \\
$30-$ & 135 & 25.67 \\
$40-$ & 161 & 30.61 \\
$50-$ & 121 & 23.00 \\
$60-$ & 81 & 15.40 \\
$70-$ & 12 & 2.28 \\
\hline Total & 526 & 100.00 \\
\hline
\end{tabular}

The youngest was 22 years old and the oldest 75 years old. The peak incidence was in the $5^{\text {th }}$ decade ( $30.61 \%$ ), followed by the 4 th decade with $25.67 \%$. Under 40 years of age there were $28.71 \%$ of the cases. Compare to cases from $\mathrm{CIH}$, the case distribution of breast cancer by age is seen in Table 7 .

Table 7. Case distribution of breast cancer cases by age

\begin{tabular}{lrrrr}
\hline \multirow{2}{*}{ Age } & \multicolumn{2}{c}{ RSCM (1988-1995) } & \multicolumn{2}{c}{ CIH (1989) } \\
\cline { 2 - 5 } & No. of cases & $\%$ & No. of cases & \multicolumn{1}{c}{$\%$} \\
\hline $20-$ & 16 & 3.04 & 2 & 0.4 \\
$30-$ & 135 & 25.67 & 59 & 13.2 \\
$40-$ & 161 & 30.61 & 171 & 38.8 \\
$50-$ & 121 & 23.00 & 120 & 26.9 \\
$60-$ & 81 & 15.40 & 74 & 16.6 \\
$70-$ & 12 & 2.28 & 17 & 3.8 \\
$80-$ & - & - & 3 & 0.7 \\
\hline Tot a l & 526 & $100 \%$ & 446 & $100 \%$ \\
\hline
\end{tabular}

Both groups have the same peak incidence in the $5^{\text {th }}$ decade, with an incidence of $30.61 \%$ at RSCM and $38.3 \%$ at $\mathrm{CIH}$. In the $4^{\text {th }}$ decade, the incidence was almost twice compare to the $\mathrm{CIH}$ cases $(25.67 \%)$ against $13.2 \%$ ). Also in the 3 rd decade the RSCM had more number of cases, with a $3 \%$ difference. The case distribution by size of tumor of the $2^{\text {nd }}$ batch and compare to the cases from $\mathrm{CIH}$ is shown in Table 8. The data were available in only 199 cases.

Table 8. Cases distribution by size of tumor

\begin{tabular}{lrrrr}
\hline \multirow{2}{*}{$\begin{array}{l}\text { Size of } \\
\text { Tumor }\end{array}$} & \multicolumn{2}{c}{ RSCM (1992-1995) } & \multicolumn{2}{c}{ CIH (1989) } \\
\cline { 2 - 5 } & No. of cases & $\%$ & No. of cases & $\%$ \\
\hline T0 & - & - & 22 & 4.9 \\
T1 & 3 & 1.50 & 182 & 40.8 \\
T2 & 36 & 18.09 & 191 & 42.8 \\
T3 & 36 & 18.09 & 21 & 4.7 \\
T4 & 124 & 62.31 & 30 & 6.7 \\
\hline T o t a 1 & 199 & $100 \%$ & 446 & $100 \%$ \\
\hline
\end{tabular}

The RSCM T1 + T2 accounted for $19.59 \%$, while at $\mathrm{CIH}$ it was $83.6 \%$. The reserved occurred for $\mathrm{T} 3$ and T4. At RSCM it was $80.4 \%$, at CIH only $11.4 \%$.

\section{DISCUSSION}

In this study we used the classification proposed by the Japanese Breast Cancer Society, which is essentially the same as the WHO classification with a minor modification. The invasive ductal carcinoma $($ WHO NOS/NST $)=$ No otherwise specified/No special type) which in reality has different pattern of infiltration is further sub-classified into 3 sub-types, namely papillotubular, solid-tubular and scirrhous carcinoma, which have prognostic significance. They also reflect the degree of differentiation, which from poor to well is in an order of scirrhous ca, solid ca and papillotubular ca. The scirrhous carcinoma has the poorest prognosis. This subclassification can be used instead of the grading system. There were several grading systems proposed,8,9 but we are still looking for an Internationally recognized breast cancer grading system. Using this classification we could avoid the universal problem of the grading of breast cancer.

In the second batch of the study we found only 1 cases of noninvasive ductal carcinoma $(0.46 \%)$ among 215 cases of breast cancer, while in the batch 
of the study, we encountered 4 cases (1.33\%) among 300 cases of breast cancer. When we combined the cases (Batch $1 \& 2$, RSCM) and compared with the cases from Japan (CIH), we found that the incidence of noninvasive ductal carcinoma was lower at the RSCM, with a $6.43 \%$ difference. The earlier detection of breast cancer could be responsible for the difference, especially with mammography screening which has led to increase detection of ductal carcinoma in situ (noninvasive ductal carcinoma). 11

All our cases of noninvasive ductal carcinoma/ductal carcinoma in situ (DCIS) were of the comedo type. In our previous study, other subtypes were also encountered, such as the micropapillary, cribriform and the solid variety. 12 The increased prevalence of ductal carcinoma in situ (DCIS) has produced a growing awareness of the importance of its diverse pattern and have become clinically significant as predictive indicators of success for planned local excisions of small DCIS lessions. ${ }^{13}$

Bellamy et al 14 in a review of 130 cases of noninvasive ductal carcinoma of the breast concluded that the comedo carcinoma DCIS had an occult presentation significantly more likely than other patterns to involve multiple quadrants of breast, irrespective of nuclear grade or necrosis. Our cases of DCIS were detected at early stages (I and II).

In the second batch, the invasive ductal carcinoma accounted for $90.24 \%$ of the cases, followed by the special types with $9.3 \%$. In the first batch of the study we found $88.33 \%$ of invasive ductal carcinoma and $9.67 \%$ of the special types. The $\mathrm{CIH}$ cases accounted for $80.4 \%$ and $11.3 \%$ respectively. The invasive ductal carcinoma was the most common, accounting for at least $80 \%$ of breast cancer.

Among the subtypes of invasive ductal carcinoma, the RSCM cases had $50.49 \%$ of the scirrhous type (Table 4), followed by the solid-tubular type of $28.16 \%$ and the papilotubular type of $10.49 \%$.

While the $\mathrm{CIH}$ cases had $43.6 \%$ scirrhous type, followed by the papilotubular type of $19.3 \%$ and the solid-tubular type was the least common. The subclassification of invasive ductal carcinoma into 3 sub-types has prognosis significance. The scirrhous carcinoma shows the worst prognosis, with a ten-year survival rate of $61.2 \%$. The papilotubular carcinoma shows the most favorable prognosis, with a ten-year survival rate of $77.4 \%$. The ten-year survival rate for solid-tubular carcinoma is $64.9 \%$.

The RSCM cases had $9.50 \%$ of the special types, while at the $\mathrm{CIH}$ it was $11.3 \%$ (Table 4). Among the special types at the RSCM, only 5 variants were encountered, while at the $\mathrm{CIH}$, there were 7 variants, including spindle cell carcinoma, apocrine carcinoma and tubular carcinoma. We had one case of adenoid cystic carcinoma, which was found at the $\mathrm{CIH}$. The incidence rates of mucinous and invasive lobular carcinoma at the RSCM were lower than at the CIH, while the medullary carcinoma was higher $(5.24 \%$ at the RSCM, against $1.3 \%$ at the $\mathrm{CIH}$ ). In the literature, the medullary carcinoma constitutes approximately about 5 to $8 \%$ of invasive mammary cancer. ${ }^{15}$ Histologically, they are very poorly differentiated or high-grade cancer, but has a less aggressive behavior. They are usually large $(4 \mathrm{~cm}$ or more in diameter). These features were consistent with our cases, which were presented with stage III disease at initial diagnosis.

Using the strict definition of medullary carcinoma, Ridolfi et all6 found a significantly higher overall survival rate at 10 years of $84 \%$, even when nodal metastases were present. The smaller medullary carcinoma had a better prognosis than the larger ones, but the most important prognostic feature within the group of medullary carcinoma was the density of lymphoplasmacytic infiltrate. Those patients with a relatively sparse infiltrate had a relatively poor prognosis.

We had one case of adenoid cystic carcinoma in a 52 year old woman in this study, presenting with a circumscribed lesion of $6 \mathrm{~cm}$ in diameter. It has been stated that this tumor is usually small, but may become as large as $8 \mathrm{~cm}$ in diameter, and grossly well demarcated and has a good prognosis. 15

The two cases of Paget's disease in our study were 55 years and 60 years old respectively, similar to the findings reported in the literature, that Paget's disease of the nipple tend to occur in an older age group. One case was associated with an in situ ductal carcinoma. Both cases were of stage I.

If we compared the case distribution of breast cancer by age among both groups (RSCM and $\mathrm{CIH}$ ), then we found that both groups have the same peak incidence in the $5^{\text {th }}$ decade, with an incidence of $30.61 \%$ at the RSCM and $38.3 \%$ at the $\mathrm{CIH}$. In the $4^{\text {th }}$ decade, the incidence was almost twice/doubled compare to 
the $\mathrm{CIH}$ cases $(25.67 \%$ against $13.2 \%)$. Also in the $3^{\text {rd }}$ decade, the RSCM had more number of cases, with a $3 \%$ difference. At the younger age group, breast cancer occurred more frequently in the Indonesian females as compared to the Japanese females. Table 8 showed the case distribution by tumor size of the $2^{\text {nd }}$ batch of the study. At the RSCM T1+T2 accounted for $19.59 \%$, and in the 1 st batch $\mathrm{T} 1+\mathrm{T} 2$ accounted for $19 \%$, while at the $\mathrm{CIH}$, it was $83.6 \%$. The reversed occurred for T3 and T4. At RSCM it was $80.4 \%$ (batch 2 ), or $81 \%$ (batch 1 ), while at the $\mathrm{CIH}$ only $11.4 \%$. At RSCM, the majority (more than $80 \%$ ), were of $\mathrm{T} 3+\mathrm{T} 4$ size, while at $\mathrm{CIH}$ the majority (more than $80 \%$ ) were of $\mathrm{T} 1+\mathrm{T} 2$ size. At their presentation, the tumor size of breast cancer among Indonesian females was larger than that among Japanese females.

It is well established that the size of an invasive mammary cancer is an independent prognostic variable. ${ }^{17,18}$ In general, the smaller the primary tumor, the lower the chance of axillary lymph node metastases. In an analysis of 200 breast cancers treated by radical mastectomy, Fisher et al ${ }^{19}$ found that tumors less than $1 \mathrm{~cm}$ in diameter had a $22 \%$ likelihood of axillary metastases, and tumors with more that $6 \mathrm{~cm}$ in diameter had a $63 \%$ likelihood of axillary node metastases. Sakamoto et al 20 in a study of 936 cases of breast cancer surviving ten years, found that tumors between $2.1-5 \mathrm{~cm}$ in size had $51.2 \% 10$-year survival rate, and only $39.4 \%$ for tumors with greater than 5.1 $\mathrm{cm}$ in size.

\section{CONCLUSIONS}

The incidence of invasive ductal carcinoma was lower at the RSCM, with a $6.43 \%$ difference. In both groups (RSCM \& $\mathrm{CIH}$ ), the invasive ductal carcinoma was the most common, accounting for at least $80 \%$ of breast cancer. Among the special types, the incidence rates of mucinous and invasive lobular carcinoma at the RSCM were lower than at the $\mathrm{CIH}$, while the medullary carcinoma was higher.

At younger age group (20-29 years), breast cancer had already occurred more frequently in the Indonesian females as compared to the Japanese females. At their presentation, the tumor size of breast cancer among Indonesian females was larger than among Japanese females.

\section{Acknowledgments}

The authors like to thank to the nurses, Ms. Ros and
Emi, and public health nurses, Ms. July and Ms. Erlaini for excellent epidemiological data collection. We are also indebted to SDP staffs for helping in data processing.

This work was supported by the Ministry of Education, Science, Sports and Culture of Japanese Government, Grants No. 01042007, 04042013 and 06042006; and was partially supported by the Indonesian Cancer Foundation. This collaborative study was a part of Special Cancer Research project in Monbusho International Scientific Research Program, with the approval of the Dean, Faculty of Medicine, University of Indonesia, No. 4383/PT02. H4.FK/E/88.

\section{REFERENCES}

1. Elston CW, Ellis IO. Prognostic factors in breast cancer. Short Course XXth International Congress of the International Academy of Pathology, Hongkong, October 1994.

2. Waterhouse $\mathbf{J}$ et al. Cancer incidence in five continents. In: International Agency for Research on Cancer, Vol. IJI IARC publication, 1976.

3. Parkin DM, Laara E, Muir CS. Estimates of the worldwide frequency of sixteen major cancers in 1980 . In J Cancer 1988; 41: 184-97.

4. NG EH. The Singapore breast screening project. A preliminary report. Proceeding APCC, page 274, Singapore 1995.

5. Cornain S, Mangunkusumo R, Nasar IM, Prihartono J. Ten most frequent cancers in Indonesia: Pathology based cancer registry of 1988-1992. In: Cancer Registry in Indonesia. National Cancer Registry Center, Jakarta Coordinating Board, 1992.

6. Prihartono J, Mangunkusumo R, Partoatmodjo M, Establishing pathology based cancer registry: Indonesian experience. In: Sasaki R, Aoki K, editors. Epidemiology and prevention of cancer. Proceedings of Monbusho, (Ministry of Education, Science and Culture) International Symposium on Comparative Study on Etiology \& Prevention of Cancer, Nagoya 1989. Nagoya: The University of Nagoya Press, 1990: $211-6$.

7. Japanese Breast Cancer Society. The General Rules for Clinical and Pathological Recording of Breast Cancer. Jpn J Surg 1989; 19: 613-32.

8. Hartmann WH, Ozello L, Sobin LH, Stalsberg H. Histological typing of breast tumors. In: International Histological classification tumors, No.2 $2^{\text {nd }}$ ed. Geneva: WHO, 1981.

9. Dalton LW, Page DL, Dupont WD: Histologic grading of breast carcinoma. A reproducibility study. Cancer 1994; 72 : 2765-70.

10. Elston CW, Ellis IO. Pathological prognostic factors in breast cancer. I. The value of histological grade in breast cancer: experience from a large study with long-term follow-up. Histopathology 1991; 19: 403-10. 
11. Quinn CM, Ostrowski JL, Parkin GJS, Horgan K, Benson EA. Ductal carcinoma in situ of the breast: the clinical significance of histologic classification. Histopathology 1997; 30: 113-19.

12. Tjahjadi G, Soetrisno E, Laihad PF. Pathology of malignant breast tumors. In: Cornain S, Tjahjadi G, Marwoto W, Setyawan S. eds. Malignant tumors in females. Jakarta: PAFKUI: 1986: 79-106 (in Indonesian).

13. Lennington WJ, Jensen RA, Dalton Lwl, Page DP. Ductal carcinoma in silu of the breast. Heterogeneity of individual lesions. Cancer 1994; 73: 118-24.

14. Bellamy COC, McDonald C, Salter DM, Cherry U, Anderson TJ. Noninvasive ductal carcinoma of the breast: The relevance of histologic categorization. Hum Pathol 1993; 24: 1623

15. Carter D. Interpretation of the breast biopsies. $2^{\text {nd }}$ ed. New York; Raven Press 1990: 160-4

16. Ridolfi RL, Rosen PP, Port A, Kinne D, Mike V. Medullary carcinoma of the breast. A clinicopathologic study with 10year follow up. Cancer 1997; 40: 1365-85.

17. Bedwani R,, Vann J, Rosner D, Schmitz R, Murphy G. Management and survival of female patients with "minimal" breast cancer: as observed in the long-term and short-term surveys of the American College of Surgeons. Cancer 1981; 47: 2679-88.

18. Rosen PP, Groshen HF, Saigo PE, Kinne DW, Hellman S. A long-term follow up study of survival in stage I (T1NoMo) and stage Il (T1NoMo) breast carcinoma. J Clin Oncol 1989; 7: 355-66

19. Fisher B, Slack NH, Bross ID and cooperating investigators. Cancer of the breast: Size of neoplasm and prognosis. Cancer 1969; 24: 1071-80.

20. Sakamoto G, Sugano H, Hartmann WH. Comparative pathological study of breast carcinoma among American and Japanesc women. In: McQuire WL.ed. Breast cancer. Nashville; Plenum 1981: 211-31.

\section{APPENDIX}

\section{A. Principles of classification}

1. Breast carcinoma is classified into three groups; noninvasive carcinoma, invasive carcinoma and Paget's disease.

2. Noninvasive carcinoma is classified into noninvasive ductal carcinoma and lobular carcinoma in situ; Invasive carcinoma into invasive ductal carcinoma and special types.

3. Invasive ductal carcinoma is further classified into three subgroups; papilotubular carcinoma, solid-tubular carcinoma and scirrhous carcinoma.

\section{B. Definition of histological types}

1. Invasive carcinoma

This group represents a carcinoma with invasion.

2a. Invasive ductal carcinoma

This is classified into three subgroups; papilotubular carcinoma, solid-tubular carcinoma and scirrhous car- cinoma. Classification of invasive carcinoma follows the rule of predominancy when there are two or more histological patterns. In a case where judgement of the predominant type is difficult, the least differentiated type should be chosen as the histological type, with supplementary description of other histological types. Remark 1:

In practice, the predominant histological type should be taken for the principal classification, and the secondary histological type should be added as a supplementary description.

Remark 2:

The degree of differentiation from poor to well is in order of scirshous carcinoma, solid-tubular carcinoma and papilotubular carcinoma.

Remark 3:

A lesion with slight extraductal invasion should be so described for easier correspondence with the WHO classification.

\section{2.a1. Papilotubular carcinoma}

This carcinoma is characterized by papillary projection and tubule formation, and may contain a solid pattern inpart. Comedocarcinoma belongs to this type.

Remark 1:

Comedocarcinoma should be identified as that. Remark 2:

Papillary carcinoma which is an independent histological type in the WHO classification has been included in papilotubular carcinoma. However, there is still room for further consideration.

2.a2. Solid-tubular carcinoma

This is a carcinoma characterized by a solid cluster of cancer cells with expansive growth forming sharp borders.

Note: Since this type is characterized by dis tinct bounderies, tumors composed of medullary and/or solid nests are also included, even if interstitial components of stromal tissue are present. Central necrosis or fibrosis may also be evident.

\section{2.a3. Scirrhous carcinoma}

Cancer cells of this histologic type show scattered invasion into the stroma in small clusters or in trabecular structures with accompanying desmoplasia of varying degrees. There are two subtypes. One is a pure scirrhous carcinoma which has extremely small amount of intraductal component and extensive stromal invasion. The other derives from papilotubular or solid-tubular carcinoma with a predominance of diffuse stromal invasion.

Note: The differential diagnosis between scirrhous carcinoma and solid-tubular carcinoma relies on the size of cancer nests and the fashion of filtration at the tumor margin. Scirrhous carcinoma is composed of small nests, grows diffusely and infiltrates into the stromal tissue. On the other hand, solid-tubular carcinoma has large nets, grows expansively and is well circumscribed. 